\title{
Importância do Treinamento de Residentes em Eventos Adversos durante Anestesia. Experiência com o Uso do Simulador Computadorizado *
}

\section{Importance of Critical Events Training for Anesthesiology Residents. Experience with Computer Simulator}

Domingos Dias Cicarelli, TSA ${ }^{1}$; Ricardo Boari Coelho ${ }^{2}$; Fábio Ely Martins Benseñor ${ }^{3}$; Joaquim Edson Vieira, TSA ${ }^{4}$

\section{RESUMO}

Cicarelli DD, Coelho RB, Benseñor FEM, Vieira JE - Importância do Treinamento de Residentes em Eventos Adversos durante Anestesia. Experiência com o Uso do Simulador Computadorizado

JUSTIFICATIVA E OBJETIVOS: Em decorrência da grande evolução da monitorização e do arsenal terapêutico disponível nos últimos anos, houve uma redução na incidência de eventos adversos durante procedimentos anestésicos. Porém, continua importante o treinamento dos médicos residentes para este tipo de ocorrência. O objetivo deste estudo foi avaliar o desempenho prático do residente de Anestesiologia em eventos adversos durante uma anestesia simulada.

MÉTODO: Foram avaliados 17 médicos em especialização do primeiro e segundo anos de Anestesiologia $\left(M E_{1}\right.$ e $\left.M E_{2}\right)$ e 5 instrutores do Centro de Ensino e Treinamento (CET) do HCFMUSP (Título Superior em Anestesiologia - TSA). Foi utilizado o simulador computadorizado Anesthesia Simulator Consultant (ASC) versão 2.0 - 1995 / Anesoft para realização das simulações dos eventos. Os incidentes críticos escolhidos foram fibrilação ventricular (FV) e choque anafilático. Após a realização da simulação, foram impressos os resultados de cada participante e avaliadas e pontuadas as condutas adotadas para resolver os incidentes críticos pré-determinados. Os participantes avaliaram o simulador através do preenchimento de um questionário.

RESULTADOS: Não houve diferença estatística entre as médias obtidas pelos grupos, porém notou-se uma tendência de melhor desempenho dos grupos TSA e $\mathrm{ME}_{2}$ na simulação de FV. Com relação ao choque anafilático, houve uma tendência de melhor desempenho do grupo TSA.

CONCLUSÕES: O treinamento para diagnóstico e condutas em eventos adversos deve ser foco de atenção durante o treinamento de médicos residentes e na atualização de

\footnotetext{
* Recebido do (Received from) CET da Disciplina de Anestesiologia do Hospital das Clínicas da Faculdade de Medicina da Universidade de São Paulo (HC - FMUSP), São Paulo, SP

1. Co-Responsável do CET da Disciplina de Anestesiologia do HCFMUSP

2. $M E_{2}$ do CET da Disciplina de Anestesiologia do HCFMUSP

3. Supervisor da Unidade de Apoio Cirúrgico do HCFMUSP/Anestesiologista do HCFMUSP/ Doutor em Anestesiologia pela FMUSP

4. Anestesiologista do HCFMUSP/Doutor em Medicina pela FMUSP/Professor Colaborador da Disciplina de Clínica Geral da FMUSP
}

Apresentado (Submitted) em 03 de agosto de 2004

Aceito (Accepted) para publicação em 01 de dezembro de 2004

Endereço para correspondência (Correspondence to)

Dr. Domingos Dias Cicarelli

Av. Piassanguaba, 2933/71 Planalto Paulista

04060-004 São Paulo, SP

(C) Sociedade Brasileira de Anestesiologia, 2005

Revista Brasileira de Anestesiologia

Vol. 55, № 2, Março - Abril, 2005 anestesiologistas. O uso do simulador pode ser uma das formas de realizar o treinamento nestas situações.

Unitermos: COMPLICAÇÕES: alergia, parada cardíaca; ENSINO, Simuladores

\section{SUMMARY}

Cicarelli DD, Coelho RB, Benseñor FEM, Vieira JE - Importance of Critical Events Training for Anesthesiology Residents. Experience with Computer Simulator

BACKGROUND AND OBJECTIVES: Because of monitoring and drugs evolution, there has been a decrease in the incidence of critical events during anesthetic procedures. Despite this low frequency, critical event training for Anesthesiology residents remains important. This study aimed at evaluating Anesthesiology residents' critical care skills during computer-simulated anesthesia.

METHODS: Seventeen anesthesiology residents (first and second year) and 5 anesthesiology instructors were evaluated. Using the Anesthesia Simulator Consultant (2.0 - 1995 / Anesoft) simulations of ventricular fibrillation (VF) and anaphylactic reaction (AR) were performed. After simulation, results of each participant were printed and approaches to solve predetermined critical events were evaluated and scored. Participants have evaluated the simulator by filling out a questionnaire.

RESULTS: There were no significant differences in means obtained by groups, but there has been a trend toward better performance of second year residents and Anesthesiology instructors during VF simulation. There has been a trend toward better performance of Anesthesiology instructors during $A R$ simulation.

CONCLUSIONS: Critical events management training should be the focus during residents and anesthesiologists training. Computer simulation could be a way to carry out such training.

Key Words: COMPLICATIONS: allergy, cardiac arrest; TRAINING, Simulators

\section{INTRODUÇÃO}

Estin stima-se que o conhecimento científico dobre a cada 6 anos, o que provocou acentuadas mudanças na prática anestésica nos últimos 10 anos ${ }^{1}$.

Dados de revisão da mortalidade associada aos procedimentos anestésico-cirúrgicos mostram diminuição da mortalidade nos últimos 50 anos $^{2}$, ao mesmo tempo em que procedimentos cirúrgicos mais complexos são realizados em pacientes mais idosos ${ }^{3}$. O conceito de que a habilidade do provedor influencia diretamente a qualidade do serviço prestado é fundamental em todos os aspectos da sociedade ${ }^{3}$. A partir desse conceito, pode-se esperar que quanto mais 
anestesiologistas altamente habilitados, melhores desempenhos serão observados e menores índices de complicações peri-operatórias serão registrados ${ }^{3}$. Alguns autores ${ }^{3}$, entretanto, acreditam que a incidência de eventos adversos está diretamente relacionada a fatores de morbidade intrínsecos aos pacientes. Outros autores ${ }^{4-6}$ preconizam a reciclagem dos anestesiologistas a cada 6 meses, com vistas à manutenção de níveis adequados de habilidades e adaptação facilitada aos protocolos de conduta. Para a avaliação do conhecimento teórico do anestesiologista, as sociedades utilizam exames escritos e orais ${ }^{1,7,8}$. No entanto, torna-se um pouco mais difícil a avaliação das habilidades práticas ${ }^{1,9}$. Alguns autores acreditam no papel dos simuladores neste tipo de avaliação, que poderiam complementar as avaliações orais ${ }^{10-14}$.

O uso de simuladores teve sua origem em outros ramos de atividade como a indústria da aviação e nuclear, em que os operadores devem estar atentos e treinados para enfrentar qualquer intercorrência. A reprodutibilidade dessas intercorrências, sem trazer conseqüências catastróficas, só é possível com o uso da simulação ${ }^{10,14-18}$. A Anestesiologia é uma das especialidades médicas em que se observa grande semelhança com esses ramos de atividade.

Os simuladores de anestesia podem promover o desenvolvimento e manutenção de habilidades e permitir respostas rápidas a incidentes raros, porém graves numa anestesia 4,10,11,15,19-21. A partir dessas características, seu uso pode ser parte essencial no treinamento e na avaliação do desempenho individual e de equipes durante situações críticas 11,13,22-25. Uma das limitações à disseminação do seu uso é o grande custo dos simuladores de alta fidelidade ${ }^{5,10,18,24,26-29}$ e a falta de realismo dos simuladores de baixa fidelidade 10,18,29,30-32. Porém, mesmo os simuladores computadorizados de baixa fidelidade como o Anesthesia Simulator Consultant (ASC) ${ }^{10,33}$ têm sido utilizados para treinamento e ensino, com resultados positivos ${ }^{10,31,32}$.

O objetivo deste estudo é avaliar o desempenho dos médicos residentes e instrutores frente a incidentes críticos simulados ${ }^{34,35}$.

\section{MÉTODO}

Após aprovação pela Comissão de Ética desta instituição, 22 médicos participaram do estudo, sendo 11 médicos em especialização de $1^{\circ}$ ano $\left(\mathrm{ME}_{1}\right), 6$ médicos em especialização de $2^{\circ}$ ano $\left(\mathrm{ME}_{2}\right)$ e 5 anestesiologistas instrutores de Centro de Ensino e Treinamento (CET), pertencentes ao corpo clínico do Hospital das Clínicas da Faculdade de Medicina da Universidade de São Paulo. Os participantes do estudo preencheram um questionário a respeito dos cursos de imersão ou reciclagem de que participaram nos últimos dois anos.

Foi utilizado o simulador Anesthesia Simulator Consultant (ASC) versão 2.0 - 1995/ Anesoft para realização das simulações. Este simulador contém 4 pacientes diferentes para serem anestesiados, com 11 possibilidades de incidentes críticos e modelos fisiológicos e farmacológicos usados na determinação dos efeitos das várias intervenções.
Após o caso ser selecionado, aparece na tela do computador uma história clínica e um exame físico sucinto do paciente, que não são mais acessados após o início da simulação. O simulador permite que o anestesiologista examine o paciente, administre fármacos, controle as vias aéreas, ventile e administre fluídos com a utilização do mouse. Permite, ainda, a monitorização em tempo real da cardioscopia, oximetria de pulso, pressão arterial não-invasiva e invasiva, capnografia, analisador de gases e temperatura.

Na tela, aparece um aparelho de anestesia com fluxômetros, vaporizadores e uma figura do paciente com o tipo de controle da via aérea (máscara facial, tubo traqueal) (Figura 1).

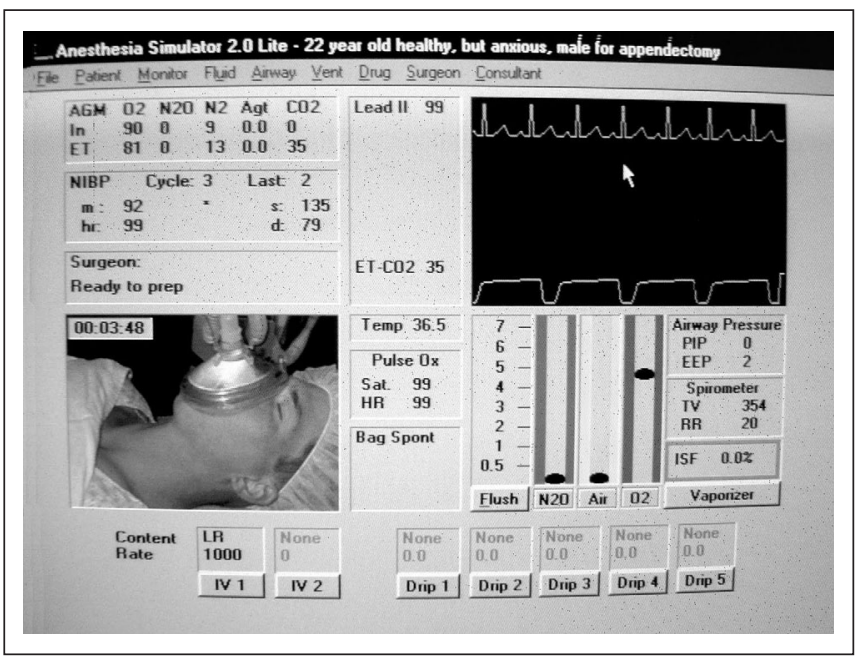

Figura 1 - Tela do Computador com Simulação

No menu, no alto da tela, encontram-se opções como Patient (ruídos respiratórios, estado neurológico, pulso); Vent (verificação do circuito respiratório, ventilação espontânea, controlada); Monitor (TOF, pressão arterial não-invasiva e invasiva); Fluids (cristalóides, colóides), Airway (colocação da máscara facial, laringoscopia); Drugs (opióides, bloqueadores neuromusculares, drogas de ação cardiovascular); Surgeon (preparação, incisão, iniciando reanimação cardiovascular).

Para um contato prévio dos participantes com o simulador, uma anestesia simulada sem intercorrências foi realizada com duração aproximada de 15 minutos. Logo após, o participante realizava outras duas anestesias, sendo simulados dois incidentes críticos de alta gravidade e grande potencial para evolução a óbito, quando não tratados ${ }^{36}$ : choque anafilático e fibrilação ventricular (FV). Para evitar que uma eventual falta de habilidade no manuseio do mouse e do computador interferisse no desempenho do anestesiologista, um médico não participante do estudo manuseou o mouse de acordo e em tempo hábil com as ordens verbais dos participantes.

A simulação do choque anafilático iniciou-se com liberação de histamina poucos minutos após a administração do primeiro agente anestésico, causando taquicardia, vasodilatação e hipotensão. A maior diminuição da pressão arterial ocorreu 
em três minutos, aparecendo eritema cutâneo durante este período. Após 5 minutos, a ausculta pulmonar revelava sibilos, com aumento da pressão traqueal e alteração da capnografia. Caso nenhum tratamento fosse instituído para corrigir a pressão arterial, o paciente evoluiria para parada cardíaca. O tratamento da hipotensão arterial prevenia a parada cardíaca, mas o tratamento definitivo incluía administração agressiva de fluídos e epinefrina 2 a $3 \mu \mathrm{g} . \mathrm{kg}^{-1}$.

Após a primeira simulação, outra anestesia era iniciada, porém desta vez os participantes anestesiavam um paciente que evoluía para parada cardíaca em fibrilação ventricular. 0 correto diagnóstico e a reanimação baseada no protocolo do Advanced Cardiac Life Support(ACLS) garantiam o sucesso do tratamento. A conversão para ritmo sinusal ocorria quando uma desfibrilação com 360J era feita após uma dose de epinefrina.

Realizada a simulação, foram impressos os resultados de cada participante, avaliando-se assim as condutas adotadas para resolver os incidentes críticos. Para cada situação foi definida uma escala de pontuação de condutas: sem resposta para a situação (0 ponto), intervenção compensatória definida por correção fisiológica (5 pontos), tratamento correto definido como terapia definitiva (10 pontos) ${ }^{37}$ (Quadro I). Com relação às complicações cardíacas foram utilizadas as recomendações do ACLS ${ }^{38}$ para avaliar as respostas dos participantes. Os três grupos foram comparados entre si através das notas obtidas.

Ao final da simulação, os participantes forneceram suas impressões a respeito do simulador através do preenchimento de um questionário ${ }^{39}$.

A análise estatística foi realizada pelo teste ANOVA (análise entre os grupos) ${ }^{40-42}$.

\section{RESULTADOS}

As médias dos três grupos, com relação ao desempenho nos dois eventos adversos estudados, estão na tabela I.

Tabela I - Eventos Estudados (Média \pm DP)

\begin{tabular}{lcc} 
Grupos (N) & Anafilaxia & Fibrilação ventricular \\
\hline $\mathrm{ME}_{1}(11)$ & $4,5 \pm 2,6$ & $5,9 \pm 2$ \\
$\mathrm{ME}_{2}$ (6) & $4,3 \pm 2$ & $7,5 \pm 2,7$ \\
$\mathrm{TSA}(5)$ & $7 \pm 2,7$ & $8 \pm 2,7$ \\
\hline
\end{tabular}

ME - médico em especialização

TSA - médico portador do Título Superior em Anestesiologia, instrutor do CET/SBA
Não houve diferença estatística significativa entre a média dos três grupos estudados.

A avaliação dos questionários evidenciou algumas características dos participantes. Todos os instrutores de CET tinham entre 5 e 10 anos de prática clínica, tendo realizado o curso do ACLS há menos de 2 anos. Todos os $\mathrm{ME}_{2}$ haviam feito o curso do ACLS há menos de 6 meses da simulação. Apenas $2 \mathrm{ME}_{1}$ haviam feito o curso até então, sendo estes dois os que obtiveram melhor desempenho na simulação de FV. Dos $17 \mathrm{ME}$ que participaram do estudo, 16 não conheciam o simulador e acharam que o uso dele pode ser útil para treinamento. Entre os aspectos positivos do uso do simulador, todos os ME consideraram que o treinamento pode melhorar a habilidade diagnóstica e a conduta adotada em eventos adversos. Em relação aos aspectos negativos do simulador, $59 \%$ dos participantes do estudo acharam que algumas situações não podem ser simuladas e $41 \%$ dos participantes acharam que a falta de realismo é o aspecto mais negativo.

Quando solicitados a enumerar as complicações vistas durante seu período de residência, cada ME já havia presenciado pelo menos um caso de parada cardíaca e um episódio de broncoespasmo durante seu treinamento. Entre os $17 \mathrm{ME}$, apenas um relatou ter presenciado um caso de choque anafilático.

\section{DISCUSSÃo}

Apesar de não haver diferença estatística entre as notas obtidas, houve uma tendência aparente de melhor desempenho com relação ao evento FV nos dois grupos cujos integrantes já haviam participado do curso do ACLS ( $\mathrm{ME}_{2}$ e TSA). No grupo de $\mathrm{ME}_{1}$, os dois participantes que já haviam feito o ACLS foram os que tiveram melhor desempenho no tratamento da FV. Esta tendência observada é concordante com os resultados de outros autores ${ }^{6}$ que afirmam que indivíduos submetidos a treinamentos específicos apresentam melhor desempenho que os não treinados. Schwid e col. ${ }^{6}$ afirmaram ainda que a retenção do conhecimento, após um treinamento específico, é maior por um período de 6 meses e que após dois anos do treinamento, o indivíduo treinado e o não treinado têm o mesmo desempenho.

Com relação ao CET do HCFMUSP, pode-se reafirmar a importância da obrigatoriedade dos $\mathrm{ME}_{2}$ em realizar o curso do ACLS, visando à complementação do treinamento em situações adversas ${ }^{43}$.

Quadro I - Simulações e Sistema de Pontuação

\begin{tabular}{|c|c|c|c|}
\hline Eventos Adversos & Manifestação Clínica & Intervenção Compensatória (5 pontos) & Terapia Definitiva (10 pontos) \\
\hline Choque anafilático & $\begin{array}{l}\text { Taquicardia, hipotensão arterial, } \\
\text { broncoespasmo }\end{array}$ & $\begin{array}{l}\text { Administração de vasopressores e } \\
\text { fluídos }\end{array}$ & Administração de fluídos e epinefrina \\
\hline Fibrilação ventricular & $\begin{array}{l}\text { Mudança do traçado eletrocardio- } \\
\text { gráfico com ausência de pressão arte- } \\
\text { rial e pulso }\end{array}$ & $\begin{array}{l}\text { Diagnóstico de parada cardíaca pela } \\
\text { ausência de pulso e início da } \\
\text { massagem cardíaca externa e } \\
\text { administração de epinefrina }\end{array}$ & $\begin{array}{l}\text { Diagnóstico da fibrilação ventricular e } \\
\text { início da desfibrilação e administração } \\
\text { de epinefrina }\end{array}$ \\
\hline
\end{tabular}


Os resultados obtidos na simulação do choque anafilático evidenciam outra situação. Como nenhum dos ME foi submetido a um treinamento específico para esta situação, observou-se que as médias dos grupos de $\mathrm{ME}_{1}$ e $\mathrm{ME}_{2}$ foram muito semelhantes, com tendência a serem menores do que o grupo TSA. Esta observação pode ser explicada pela falta de treinamento específico para esta situação e pelo fato de que o choque anafilático é complicação cada vez menos freqüente na prática clínica. O tempo maior de experiência prática pode ser o único fator que diferenciou os grupos ${ }^{44}$. Assim sendo, a experiência adquirida com a clínica pode fazer diferença quanto ao diagnóstico rápido e à conduta adequada ${ }^{6}$. É preciso levar em consideração na análise dos resultados, que este simulador não possui nenhum tipo de alarme como o aparelho de anestesia e os monitores, fato este que impede que o médico avaliado tenha sua atenção desviada para alguma alteração apresentada pelo paciente de uma forma passiva. O simulador impõe ao participante do estudo, uma busca ativa das alterações que ocorrem com o paciente. $\mathrm{O}$ melhor exemplo desta situação foi a simulação do choque anafilático. A maioria dos participantes fez o diagnóstico de broncoespasmo e tratou o paciente sem procurar ativamente por algum outro sinal clínico, como o eritema cutâneo. Muitas vezes durante uma anestesia, o anestesiologista tem sua atenção desviada para algum sinal clínico do paciente de forma passiva, como a simples observação de um eritema, fazendo o diagnóstico sem que tivesse havido um raciocínio lógico ou uma busca ativa para realizar este diagnóstico. Neste estudo, $83 \%$ dos participantes concordou na possível utilidade do simulador para treinamento de situações críticas pouco freqüentes durante a anestesia, mas de importância significativa na formação dos ME. Porém é preciso ressaltar a importância da correta supervisão deste treinamento para que se obtenha o melhor resultado possível ${ }^{45}$.

A maior crítica ao ASC foi a dificuldade em simular algumas situações, bem como a falta de realismo. Este fato pode ser minimizado com o uso de simuladores de alta fidelidade, porém o alto custo deste tipo de simulador impede sua disseminação e diminui a importância do impacto positivo do maior realismo. O simulador usado neste estudo, apesar da sua baixa fidelidade, pode cumprir um papel importante no treinamento de residentes ${ }^{11}$, sendo que seu custo o torna acessível a qualquer anestesiologista ou CET ${ }^{45}$.

O treinamento para diagnóstico e conduta em eventos adversos deve ser foco constante de atenção durante o treinamento dos médicos residentes e na atualização dos anestesiologistas.

\section{Importance of Critical Events Training for Anesthesiology Residents. Experience with Computer Simulator}

Domingos Dias Cicarelli, TSA, M.D.; Ricardo Boari Coelho M.D.; Fábio Ely Martins Benseñor M.D.; Joaquim Edson Vieira, TSA, M.D.

\section{INTRODUCTION}

Scientific knowledge is estimated to double every 6 years and this has led to marked changes in anesthetic practice in the last 10 years ${ }^{1}$.

Data on anesthetic and surgical related mortality show decreased mortality in the last 50 years ${ }^{2}$, while at the same time more complex surgical procedures are performed in older patients ${ }^{3}$. The concept that provider's skills directly influence quality of service is critical for all aspects of society ${ }^{3}$.

Accordingly, one may assume that with more highly skilled anesthesiologists better performances will be observed and lower perioperative complication rates will be recorded ${ }^{3}$. Some authors ${ }^{3}$, however, believe that the incidence of adverse events is directly related to morbidity factors intrinsic to patients. Other authors ${ }^{4-6}$ recommend anesthesiologists updating courses every 6 months to maintain adequate skills and help adaptation to management protocols. Societies adopt written and oral tests to evaluate the theoretical knowledge of anesthesiologists ${ }^{1,7,8}$. Practical skills, however, are slightly harder to evaluate ${ }^{1,9}$. Some authors believe in the role of simulators for this evaluation, which could complement oral evaluations ${ }^{10-14}$.

Simulators had their origin in different activities, such as aircraft and nuclear industries, where operators have to be alert and trained to face critical events. Reproducing such events without any catastrophic consequence is only possible with the aid of a simulator ${ }^{10,14-18}$. In this sense, anesthesiology is a medical specialty very similar to the mentioned activities.

Anesthesia simulators may promote skills development and maintenance and provide prompt responses to uncommon, however severe, anesthetic incidents ${ }^{4,10,11,15,19-21}$. Due to such characteristics, they may become essential to training and evaluation of individual and teams performance during critical situations ${ }^{11,13,22-25}$. One limitation to their wide use is the high cost of high fidelity simulators ${ }^{5,10,18,24,26-29}$ and the lack or realism of low fidelity simulators ${ }^{10,18,29,30-32}$. However, even low fidelity computer simulators such as Anesthesia Simulator Consultant (ASC) ${ }^{10,33}$ have been used for training and teaching with positive results ${ }^{10,31,32}$.

This study aimed at evaluating the performance of resident anesthesiologists and instructors exposed to simulated critical events ${ }^{34,35}$.

\section{METHODS}

After the institution's Ethics Committee approval, participated of this study 22 physicians being 11 first year residents, 
6 second year residents and 5 anesthesiology instructors of the Teaching and Training Center and belonging to the clinical team of Hospital das Clínicas, Faculdade de Medicina, Universidade de São Paulo. Participants answered a questionnaire about in-depth or updating courses they had attended in the last 2 years.

Anesthesia Simulator Consultant (ASC) version 2.0 - 1995 / Anesoft was used for simulations. This simulator has 4 different patients to be anesthetized with 11 possibilities of critical events and physiological and pharmacological models to be used to determine the effects of different interventions.

After selecting the case, the screen displays patient's clinical history and summarized physical evaluation, which are no longer accessed after beginning of simulation. The simulator allows the anesthesiologist to examine the patient, administer drugs, control airways, ventilate and administer fluids by clicking the mouse. It also provides real time display of ECG trace, pulse oximetry, noninvasive and invasive blood pressure, capnogram, blood gases and temperature.

An anesthesia machine with flowmeters, vaporizers and patient's image with the type of airway control (facial mask, tracheal tube) is displayed on the screen (Figure 1).

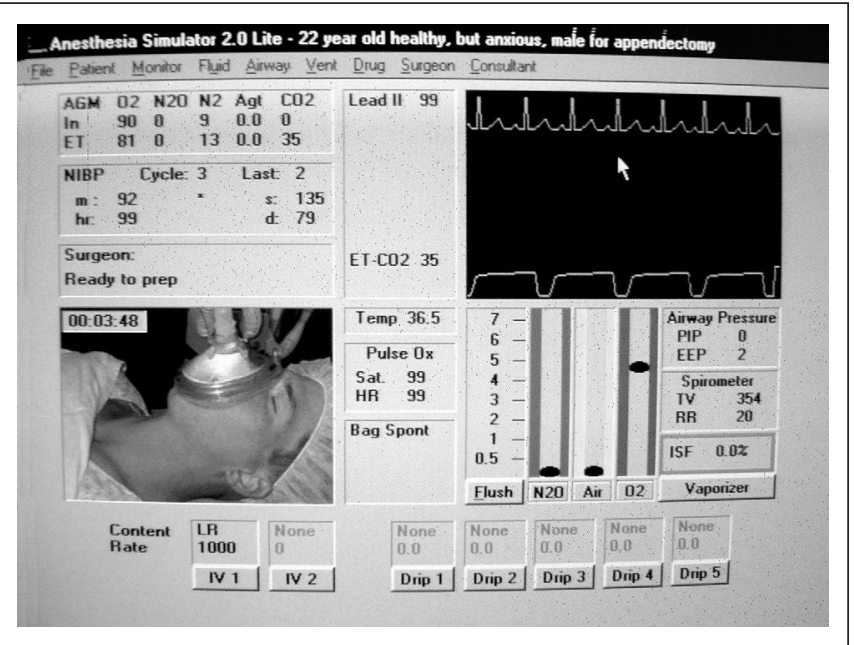

Figure 1 - Computer Screen with Simulation
The menu, on top of the screen, displays options such as $\mathrm{Pa}$ tient (respiratory sounds, neurological status, pulse); Vent (respiratory circuit checking, spontaneous, controlled ventilation); Monitor (TOF, noninvasive and invasive blood pressure); Fluids (crystalloids, colloids); Airway (facial mask adaptation, laryngoscopy); Drugs (opioids, neuromuscular blockers, cardiovascular drugs); Surgeon (preparation, incision, starting cardiac resuscitation).

A simulated anesthesia without intercurrences and lasting approximately 15 minutes was performed to familiarize participants with the simulator. Next, participant performed two anesthesias in which two highly severe, and potentially lethal if not treated, critical events were simulated ${ }^{36}$ : anaphylactic reaction (AR) and ventricular fibrillation (VF).

To prevent that potential inability in handling mouse and computer could interfere with anesthesiologist's performance, a physician not participating in the study handled the mouse according to participants' verbal orders.

Anaphylactic reaction simulation started with histamine release few minutes after the administration of the first anesthetic gas, causing tachycardia, vasodilation and hypotension. Maximal blood pressure decrease was seen in 3 minutes and was followed by skin erythema. Pulmonary auscultation revealed wheezing 5 minutes after with increased tracheal pressure and capnographic changes. If blood pressure were not corrected, patient would evolve to cardiac arrest. Treatment of hypotension would prevent cardiac arrest, but final treatment would include aggressive fluid administration and 2 to $3 \mu \mathrm{g} . \mathrm{kg}^{-1}$ epinephrine's.

After the first simulation, a second anesthesia was started, in which participants anesthetized a patient who evolved to cardiac arrest in ventricular fibrillation. Correct diagnosis and resuscitation based on Advanced Cardiac Life Support (ACLS) protocol would assure the success of the treatment. Sinus rhythm returned when $360 \mathrm{~J}$ defibrillation was performed after an epinephrine dose.

Results of each participant were printed after the simulation to evaluate the approaches adopted to solve critical events. An approach score was developed for each situation: no response to situation (0 points), compensatory intervention defined as physiological correction ( 5 points), correct treatment defined as final therapy (10 points) ${ }^{37}$ (Chart I). ACLS recommendations for cardiac complications were used to evaluate participants' responses. Groups were compared based on their scores.

At the completion of simulation, subjects filled out a questionnaire with their impressions about the simulator.

ANOVA test was used for between group comparisons ${ }^{40-42}$.

Chart I - Simulations and Scoring System

\begin{tabular}{llll}
\hline Critical Events & Clinical Manifestation & Compensatory Intervention (5 points) & Final Therapy (10 points) \\
\hline Anaphylactic reaction & $\begin{array}{l}\text { Tachycardia, hypotension, } \\
\text { bronchospasm }\end{array}$ & Administration of vasopressants and fluids & Administration of fluids and epinephrine \\
Ventricular fibrillation & $\begin{array}{l}\text { Change in ECG tracing with ab- } \\
\text { sence of blood pressure and } \\
\text { pulse }\end{array}$ & $\begin{array}{l}\text { Diagnosis of cardiac arrest by lack of pulse and } \\
\text { beginning of external cardiac massage and epi- } \\
\text { nephrine administration }\end{array}$ & $\begin{array}{l}\text { Diagnosis of ventricular fibrillation and } \\
\text { beginning of defibrillation and epineph- } \\
\text { rine administration }\end{array}$ \\
\hline
\end{tabular}




\section{RESULTS}

Table I shows means for all groups in terms of performance during both adverse events.

Table I - Studied Events (Mean \pm SD)

\begin{tabular}{lcc}
\hline Groups (N) & Anaphylaxis & Ventricular Fibrillation \\
\hline $\mathrm{RP}_{1}(11)$ & $4.5 \pm 2.6$ & $5.9 \pm 2$ \\
$\mathrm{RP}_{2}$ (6) & $4.3 \pm 2$ & $7.5 \pm 2.7$ \\
$\mathrm{TSA}(5)$ & $7 \pm 2.7$ & $8 \pm 2.7$ \\
\hline
\end{tabular}

$R P$ - resident physician

TSA - Superior Title in Anesthesiology, instructor of Anesthesiology, credentialed by the Brazilian Society of Anesthesiology

There were no statistically significant differences among means of the three groups.

Questionnaire evaluation has shown some participants' characteristics. All instructors had 5 to 10 years of clinical practice and had attended the ACLS course within the last 2 years. All second-year residents have attended the ACLS course in the last 6 months. Only two first year residents had attended the course so far and had the best performance during VF simulation.

From the 17 residents participating in the study, 16 had never seen the simulator and considered that its use might be useful for training. Among simulator's positive aspects, all residents stated that training might improve diagnostic skills and approaches for adverse events. Among negative aspects, 59\% of participants considered that some situations cannot be simulated and $41 \%$ of participants stated that lack of realism is the most negative aspect.

When asked to list complications seen during their residence period, all residents had already experienced at least one cardiac arrest and one bronchospasm during their training. Among 17 residents, only one reported having seen a case of anaphylactic reaction.

\section{DISCUSSION}

Although no statistical difference among scores was observed, there was a clear trend toward better performance with VF in the groups whose participants had already attended the ACLS course (second-year residents and instructors). Among first-year residents, two participants who had attended ACLS had the best performance with VF. This trend agrees with other authors ${ }^{6}$ who reported that individuals submitted to specific training perform better as compared to those not trained. Schwid et al. ${ }^{6}$ have even stated that knowledge retention after a specific training is higher for a 6-months period, and that trained and untrained individuals have the same performance 2 years after training.

In our institution, the ACLS course is mandatory for secondyear residents, aiming at complementing adverse events training ${ }^{43}$.

Anaphylactic reaction simulation results have shown a different picture. Since no resident had been submitted to a specific training for this situation, first and second-year resident means were very similar, with a trend to be lower as compared to instructors'. This observation may be explained by the lack of specific training for this situation and by the fact that anaphylactic reaction is a complication increasingly less frequent. Longer practical experience may be the only factor differentiating groups ${ }^{44}$. So, practical experience can make the difference for prompt diagnosis and adequate management ${ }^{6}$.

In analyzing results, it has to be considered that this simulator has no alarms as compared to anesthesia machines and monitors, which prevents the physician to have his attention shifted to some alteration passively presented by the patient. The simulator imposes to participants an active search for alterations in patients' status. Most participants diagnosed bronchospasm and treated the patient without actively looking for other clinical signs, such as skin erythema. Very often during anesthesia, the anesthesiologist has his attention shifted to some passive clinical sign, such as the mere observation of an erythema, making the diagnosis without logic reasoning or active search to confirm such diagnosis.

In our study, $83 \%$ of participants have agreed with the potential usefulness of the simulator for the training of uncommon critical events during anesthesia, and that it is of significant importance for residents training. However, it is necessary to highlight the importance of adequate training supervision to obtain the best possible result ${ }^{45}$.

Major criticism to ASC was the difficulty in simulating some situations, as well as the lack of realism. This may be minimized with high fidelity simulators, however their high cost prevents their dissemination and decreases the importance of the positive impact of more realism. In spite of its low fidelity, the simulator used in our study may play an important role in resident physicians training ${ }^{11}$, and its cost makes it affordable to any anesthesiologist or Training Center ${ }^{45}$.

Training for adverse event diagnosis and management should be a constant focus of attention during resident physicians training and anesthesiologists' updates.

\section{REFERÊNCIAS - REFERENCES}

01. Ellis FR - Measurement of competence. Br J Anaesth, 1995;75: 673-674.

02. Cicarelli DD, Gotardo AOM, Auler Jr JOC et al - Incidência de óbitos anestésico-cirúrgicos nas primeiras 24 Horas. Revisão de prontuários de 1995 no Hospital das Clínicas da FMUSP. Rev Bras Anestesiol, 1998;48:289-294.

03. Longnecker DE - Planning the future of Anesthesiology. Anesthesiology, 1996;84:495-497.

04. Nocite JR - Formação profissional: fator de segurança em anestesia. Rev Bras Anestesiol, 1993;43:3:155-156.

05. Byrne AJ, Jones JG - The expanding role of simulators in risk management. Br J Anaesth, 1997;79:411.

06. Schwid HA, O'Donnell D - Anesthesiologists management of simulated critical incidents. Anesthesiology, 1992;76:495-501.

07. Greaves JD - Anaesthesia and the competence revolution. $\mathrm{Br} J$ Anaesth, 1997;79:555-557. 
08. Eagle CJ, Martineau R, Hamilton K - The oral examination in anaesthestic resident evaluation. Can J Anaesth, 1993;40: 947-953.

09. Sivarajan M, Miller E, Hardy C et al - Objective evaluation of clinical performance and correlation with knowledge. Anesth Analg, 1984;63:603-607.

10. Gaba DM - Human Works Environment and Simulators, em: Miller RD - Anesthesia, $5^{\text {th }}$ Ed, New York, Churchill Livingstone, 2000;2613-2668.

11. Devitt JH, Kurrek MM, Cohen MM et al - The validity of performance assessment using simulation. Anesthesiology, 2001;95:36-42.

12. Liu PH - Simulators in Anesthesiology education. Anesth Analg, 1999;88:472-473

13. Kapur PA, Steadman RH - Patient simulator competency testing: ready for takeoff? Anesth Analg, 1998;86:1157-1159.

14. Doyle DJ, Arellano R - The virtual Anesthesiology training simulation system. Can J Anaesth, 1995;42:267-273.

15. Gaba DM, DeAnda A - The response of anesthesia trainees to simulated critical incidents. Anesth Analg, 1989;68:444-451.

16. Davies JM, Helmreich RL - Simulation: it's a start. Can J Anaesth, 1996;43:425-429

17. Helmreich RL, Davies JM - Anaesthetic simulation and lessons to be learned from aviation. Can J Anaesth, 1997;44:907-912.

18. Byrne AJ, Jones JG - Responses to simulated anaesthetic emergencies by anaesthetists with different durations of clinical experience. Br J Anaesth, 1997;78:553-556.

19. Burt DE - Virtual reality in anaesthesia. Br J Anaesth, 1995;75:472-480

20. Byrne AJ, Jones JG - Inaccurate reporting of simulated critical anaesthetic incidents. Br J Anaesth, 1997;78:637-641.

21. Davies JM - Simulators in Anesthesiology education. Can J Anaesth, 1998;45:1035.

22. Moll JR, Faria AA, Cella AVS et al - Simuladores de anestesia no Brasil: primeiros resultados. Rev Bras Anestesiol, 1999;49:24:160.

23. DeAnda A, Gaba DM - Unplanned incidents during comprehensive anesthesia simulation. Anesth Analg, 1990;71:77-82.

24. Spence AA - The expanding role of simulators in risk management. $\mathrm{Br} J$ Anaesth, 1997;78:633-634.

25. Byrne AJ, Hilton PJ, Lunn J - Basic simulations in anaesthesia. A pilot study of the ACCESS system. Anaesthesia, 1994;49:376-381.

26. Forrest $F$, Mather $S$, Tooley $M$ - The expanding role of simulators in risk management. Br J Anaesth, 1998;80:128.

27. Black AM - The "METI" simulator at the Bristol Medical Simulation Centre. Br J Anaesth, 1999;83:526-527.

28. Chopra V, Engbers FH, Geerts MJ et al - The Leiden anaesthesia simulator. Br J Anaesth, 1994;73:287-292.

29. Asbury AJ - Simulators for general anaesthesia. Br J Anaesth, 1994;73:285-286

30. Norman J, Wilkins D - Simulators in anaesthesia. J Clin Monit, 1996;12:91-99.

31. Chopra V, Gesink BJ, Jong J et al - Does training on an anaesthesia simulator lead to improvement in performance? $\mathrm{Br} \mathrm{J}$ Anaesth, 1994;73:293-297

32. Murray DJ - Clinical simulation: technical novelty or innovation in education. Anesthesiology, 1998;89:1-2.

33. Eisenach JC, Gutierrez KT - Anesthesia simulator consultant Version 2.0. Anesthesiology, 1995;83:1391.

34. Barreiro G, Garat J - Incidentes críticos em anestesia. Rev Bras Anestesiol, 1992;42:5:357-376.

35. Devitt JH, Kurrek MM, Cohen MM et al - Testing internal consistency and construct validity during evaluation of performance in a patient simulator. Anesth Analg, 1998;86:1160-1164.

36. DeAnda A, Gaba DM - Role of experience in the response to simulated critical incidents. Anesth Analg, 1991;72:308-315.

37. Devitt JH, Kurrek MM, Cohen MM et al - Testing the raters: inter-rater reliability of standardized anaesthesia simulator performance. Can J Anaesth, 1997;44:924-928.
38. American Heart Association - Guidelines for cardiopulmonary resuscitation and emergency cardiac care. JAMA, 1992;268:2171.

39. Kurrek MM, Fish KJ - Anaesthesia crisis resource management training: an intimidating concept, a rewarding experience. Can J Anaesth, 1996;43:430-434.

40. Noether EG - Introdução à Estatística, 2a Ed, Rio de Janeiro, Guanabara Dois, 1983;64-82.

41. Doria Filho U - Introdução à Bioestatística, $1^{\text {a }} \mathrm{Ed}$, São Paulo, Negócio Editora, 1999;77-78.

42. Hulley SB, Cummings SR - Designing Clinical Research, $1^{\text {st }}$ Ed, Philadelphia, Williams \& Wilkins, 1988;215-216.

43. Lighthall GK, Barr J, Howard SK et al - Use of a fully simulated intensive care unit environment for critical event management training for internal medicine residents. Crit Care Med, 2003;31: 2437-2443.

44. Boulet JR, Murray D, Kras J et al - Reliability and validity of a simulation-based acute care skills assessment for medical students and residents. Anesthesiology, 2003;99:1270-1280.

45. Carraretto AR - Simuladores em Anestesiologia. em: Manica J Anestesiologia. Princípios e Técnicas, $3^{a} \mathrm{Ed}$, Porto Alegre, Artmed, 2004;97-105.

\section{RESUMEN}

Cicarelli DD, Coelho RB, Beseñor FEM, Vieira JE - Importancia del Entrenamiento de los Practicantes (médicos en ejercicio) en Eventos Adversos durante la Anestesia. Experiencia con el Uso del Simulador Computadorizado

JUSTIFICATIVA Y OBJETIVOS: Con la decurrencia de la grande evolución de la monitorización y del arsenal terapéutico disponible en los últimos años, hubo una reducción en la incidencia de eventos adversos durante los procedimientos anestésicos. Sin embargo, continua importante el entrenamiento de los médicos practicantes para este tipo de ocurrencia. El objetivo de este estudio fue evaluar el desempeño práctico de los médicos practicantes de Anestesiología en eventos adversos durante una anestesia simulada.

MÉTODO: Fueron evaluados 17 médicos en especialización de primero y segundo años de Anestesiología $\left(M E_{1}\right.$ y $\left.M E_{2}\right)$ y 5 instructores del Centro de Enseñanza y Entrenamiento (CEE) del HCFMUSP (Título Superior en Anestesiología - TSA). Fue utilizado el simulador computadorizado Anesthesia Simulator Consultant (ASC) versión 2.0 - 1995/Anesoft para realización de las simulaciones de los eventos. Los incidentes críticos escogidos fueron fibrilación ventricular (FV) y choque anafiláctico. Después de la realización de la simulación, fueron impresos los resultados de cada participante, evaluados y puntuados las conductas adoptadas para resolver los incidentes críticos pre-determinados. Los participantes evaluaron el simulador a través de un cuestionario para ser respondido.

RESULTADOS: No hubo diferencia estadística entre las medias obtenidas por los grupos, sin embargo, se notó una tendencia de un desempeño mejor de los grupos TSA y ME $\mathrm{M}_{2}$ en la simulación de FV. En relación al choque anafiláctico, hubo una tendencia de desempeño mejor del grupo TSA.

CONCLUSIONES: El entrenamiento para el diagnóstico y conductas en eventos adversos debe ser un foco de atención durante el entrenamiento de médicos practicantes y en la actualización de anestesiologistas. El uso del simulador puede ser una de las formas de realizar el entrenamiento en estas situaciones. 